\title{
Piperaceae na Reserva Biológica de Poço das Antas, Silva Jardim, Rio de Janeiro, Brasil
}

\author{
Elsie Franklin Guimarães ${ }^{1} \&$ Daniele Monteiro $^{2}$
}

\begin{abstract}
Resumo
(Piperaceae na Reserva Biológica de Poço das Antas, Silva Jardim, Rio de Janeiro, Brasil) O estudo taxonômico das Piperaceae da Reserva Biológica de Poço das Antas foi realizado com base em material herborizado, observações de campo e compreende chave para identificação, descrições e distribuição geográfica dos táxons. Comentários sobre a importância medicinal, dados fitoquímicos e uso são atribuídos a algumas espécies. Foram assinalados para esta Reserva 27 táxons, alguns pouco coletados para o estado do Rio de Janeiro, como Piper translucens, somente conhecido até então pelo material tipo. De um modo geral, os táxons nesta área preferem locais úmidos e sombrios, podendo também ser encontrados em áreas degradadas em pleno sol.
\end{abstract}

Palavras chave: Piperaceae, taxonomia, flora, Poço das Antas.

\section{Abstract}

(Piperaceae of the Biological Reserve of Poço das Antas, Silva Jardim, Rio de Janeiro, Brazil) The taxonomical study of the Piperaceae occurring in the Biological Reserve of Poço das Antas was carried out based on herbarium material, field observations and identification keys, descriptions and geographical distribution of the taxa are presented. Comments about the medicinal relevance, phytochemical data and use are given to some species. For this reserve 27 taxa were analyzed, some of them are poorly collected in the state of Rio de Janeiro, such as Piper translucens, wich was known so far by the type material. In general, the taxa in this area prefer humid and shady places, being also found in devastated areas and completed exposed to the sun.

Key words: Piperaceae, taxonomy, flora, Poço das Antas.

\section{INTRODUÇÃo}

As Piperaceae englobam cerca de 2500 espécies, e são distribuídas em cinco gêneros de distribuição tropical e subtropical; no Brasil está constituída por quatro gêneros e cerca de 500 espécies (Yuncker, 1972, 1973 e 1974). De importância econômica e medicinal, algumas espécies fazem parte do mercado mundial, como a pimenta-do-reino (Piper nigrum L.) e outras são usadas de modo empírico pelas populações em diferentes doenças; outros como Piper betle L., P. methysticum G. Forst. são conhecidos mastigatórios. Muitas espécies de Peperomia são cultivadas como ornamentais, cuja beleza reside principalmente em sua folhagem, enquanto outras são utilizadas na alimentação. Com base nos estudos encetados por Yuncker deu-se continuidade no Brasil às pesquisas na família Piperaceae. Neste trabalho ao seguir-se Yuncker (1972, 1973, 1974) considerou-se o gênero Ottonia.

\section{Material e Métodos}

O material botânico utilizado neste estudo foi obtido de coletas realizadas pela primeira autora, entre os anos de 1981, 1983 e 1984 e, de coletas feitas pelo Programa Mata Atlântica em diversas áreas da Reserva. Quando as informações dos materiais se mostraram insuficientes, foram examinados materiais adicionais; os materiais quando

Artigo recebido em 02/2005. Aceito para publicação em 12/2005.

${ }^{1}$ Bolsista do CNPq. / Pesquisadora do Instituto de Pesquisas Jardim Botânico do Rio de Janeiro. Programa Mata Atlântica. Rua Pacheco Leão 915, Jardim Botânico, Rio de Janeiro, RJ, 22460-030. eguimar@jbrj.gov.br ${ }^{2}$ Bolsista CAPES / Mestranda da Escola Nacional de Botânica Tropical. ENBT/JBRJ - Programa Mata Atlântica. daniele@jbrj.gov.br 
estéreis, adotou-se a abreviação "st", na lista de material examinado.

No estudo taxonômico, seguiu-se a conceituação de Yuncker (1972, 1973, 1974), sendo utilizados materiais dos herbários: $\mathrm{R}, \mathrm{RB}$, GUA e M (siglas de acordo com Holmgren et al. 1990). As formações vegetais citadas seguem o sistema de classificação de Veloso et al. (1991).

Os desenhos em nanquim ilustram os detalhes considerados relevantes para melhor identificação dos táxons e foram realizados com o auxílio de microscópio estereoscópico Willd, equipado com câmara clara. As espécies são apresentadas em ordem alfabética e os comentários inseridos no texto foram extraídos de literatura, informações pessoais e das etiquetas das exsicatas consultadas.

\section{Resultados e Discussão}

Piperaceae C. Agardh, Aphor. bot. 14: 201. 1824.

Ervas eretas epífitas, terrestres, arbustos ou arvoretas. Folhas estipuladas, alternas, opostas ou verticiladas, inteiras, sésseis ou pecioladas, de consistência e formatos os mais diversos, indumento muito variado, geralmente dotadas de glândulas translúcidas. Flores aclamídeas, mínimas, andróginas ou unissexuadas, protegidas por bractéolas pediceladas ou sésseis, sacado-galeadas, peltadas, esparsa ou densamente dispostas em racemos, umbelas ou espigas, axilares, terminais ou opostas às folhas; estames 2-6, livres ou adnatos às paredes do ovário; anteras rimosas bitecas ou unitecas; ovário súpero, séssil, geralmente imerso na raque, unilocular, uniovulado, estiloso ou não, com 1-4 estigmas, variáveis na forma; óvulo basal, ortótropo. Fruto drupa, séssil ou pedicelada. Endosperma escasso, apresentando perisperma; embrião mínimo.

$\mathrm{Na}$ Reserva foram encontrados três gêneros, 25 espécies e 2 variedades. Nesta área foram observados táxons que ocorrem em locais úmidos, em áreas sombrias, como também, aqueles que se adaptam às clareiras ensolaradas. Ressalta-se ainda, que algumas espécies são consideradas de importância ecológica, servindo de alimento para os morcegos.

\section{Chave para identificação das espécies}

1. Arbustos ou arvoretas.

2. Inflorescências com flores pediceladas

Ottonia

3. Folhas com tricomas superpostos na nervura mediana da face abaxial.. Ottonia anisum

3. Folhas glabras na nervura mediana da face abaxial.

4. Lâmina foliar 4 ou mais vezes longas do que largas Ottonia angustifolia

4'. Lâmina foliar 3 ou menos vezes longas do que largas.

5. Pedicelos mais curtos que os frutos Ottonia leptostachya

5'. Pedicelos mais longos que os frutos.

6. Lâmina foliar hirta na margem da face abaxial Ottonia albo-punctata 6'. Lâmina foliar glabra na margem da face abaxial Ottonia propinqua

2'. Inflorescências com flores sésseis Piper

7. Inflorescências com espigas dispostas em umbelas Piper umbellatum

7'. Inflorescências com espigas não dispostas em umbelas.

8. Fruto estiloso.

9. Lâmina foliar com tricomas pubescentes nas nervuras da face abaxial

Piper permucronatum

9'. Lâmina foliar glabra nas nervuras da face abaxial.

10. Lâmina foliar castanho-glandulosa; nervuras secundárias dispostas até o ápice da lâmina Piper caldense 
10'. Lâmina foliar não castanho-glandulosa; nervuras dispostas até ou abaixo da porção mediana da lâmina Piper crassinervium 8 '. Fruto não estiloso.

11. Fruto com 4 estigmas persistentes.

12. Raque glabra.

13. Folha peltada na base Piper scutifolium 13 '.Folha não peltada na base Piper translucens 12'. Raque fimbriada ou pubérula ........................... Piper hoffmannseggianum 11'. Fruto com 3 estigmas persistentes.

14. Nervuras secundárias atingindo o ápice da lâmina.

15. Bainha foliar percorrendo toda a extensão do pecíolo, formando uma ala; base da lâmina foliar profundo lobada, cordado-auriculada ou inequiláteroaguda.

16. Fruto denso-pubescentes no ápice Piper richardiifolium 16 '. Fruto glabro no ápice Piper arboreum

15'. Bainha foliar curto-basal ou alongada, constituindo um canal, não alada, às vezes sutilmente alado-caduca, até a porção mediana do pecíolo; base da lâmina foliar não profundo lobada.

17. Fruto obpiramidal, tri ou tetragonal.

18. Bractéola denso-franjada Piper divaricatum 18'. Bractéola não denso-franjada.

19. Lâmina glabra nas nervuras da face abaxial .. Piper rivinoides 19' Lâmina com tricomas hirtos nas nervuras da face abaxial

P. solmsianum var. hilarianum

17'. Fruto oblongo ou obovóide Piper amplum

14'. Nervuras secundárias dispostas até, abaixo ou pouco acima da porção mediana, não atingindo o ápice da lâmina.

20. Lâmina foliar com nervuras secundárias impressas na face adaxial, bractéola cuculado crescente, glabra ou glabrescente Piper diospyrifolium 20 '. Lâmina foliar com nervuras secundárias salientes na face adaxial, bractéola triangular ou subtriangular, peltado-franjada.

21. Lâmina foliar com tricomas híspidos ou hirsutos nas nervuras da face abaxial.

22. Pedúnculo cerca de $0,8-1,2 \mathrm{~cm}$ Piper hispidum

22'. Pedúnculo acima de $1,5 \mathrm{~cm}$ Piper malacophyllum

21'. Lâmina foliar com tricomas vilosos, sedosos ao tato

Piper mollicomum

1'. Ervas terrestres ou epífitas Peperomia

23. Todas as partes da planta nitidamente negro-glanduloso-pontuadas

Peperomia trinervis

23 '. Todas as partes da planta não nitidamente negro-glanduloso-pontuada.

24. Planta microscopicamente hirtela a glabrescente; lâmina ovada, ovado-lanceolada Peperomia corcovadensis

24'. Planta crespo-pubescente; lâmina ovado-arredondada, oblonga ....

Peperomia rotundifolia 
1. Ottonia albo-punctata Trel., Proc. Amer. Philos. Soc. 75: 696. 1935.

Arbusto 1-1,2 m alt. Caule 3-5 mm diâm., estriado. Folhas com pecíolo ca. $5 \mathrm{~mm}$ compr., estriado-canaliculado; bainha basal; lâmina 10-17 × 3,2-4,7 cm, lanceolada, papirácea, ápice acuminado, revoluta, hirta na margem da face abaxial, base aguda, peninérvea. Racemo 4,5-8 cm; raque estriado-hirta; pedúnculo 4-5 $\mathrm{mm}$ compr., estriado; pedicelos mais longos que os frutos; bractéola pedicelada, hirta na margem. Fruto ca. $3 \mathrm{~mm}$ compr., oblongo, sulcado, tetragonalapiculado no ápice.

Habitat: floresta ombrófila densa baixomontana, crescendo em local úmido.

Distribuição geográfica: Brasil, nos estados de Rio de Janeiro e São Paulo.

Material examinado: trilha do Pau Preto, margem do rio Pau Preto, 10-30 m alt., 24.I.1995, fl. e fr., J. M. A. Braga et al. 1796 (RB).

Espécie pouco coletada, contendo apenas dois exemplares para o Brasil, um assinalado no século XIX e outro no XX; pela primeira vez é citada para o estado do Rio de Janeiro. Coletada florescendo e frutificando em janeiro.

2. Ottonia angustifolia Rizz., Dusenia 3(4): 265. 1952.

Arbusto 50-70 cm alt., glabro. Caule 2$3 \mathrm{~mm}$ diâm., estriado. Folhas com pecíolo 2-5 (-8) mm compr. estriado; bainha basal; lâmina 9-20 × 1,5-2,5 cm, discolor, membranácea, papirácea, translúcida, lanceolada, oblongolanceolada, ápice acuminado, base sub-igual, inequilátera com os lados diferindo de 1-2 mm, aguda ou obtusa, margem revoluta, glabra, peninérvia, presença de glândulas. Racemo 6$8 \times 0,3-0,5 \mathrm{~cm}$, alvo-amarelado; raque angulosa, glabra ou hirtela; pedúnculo $5-8 \mathrm{~mm}$ compr., glabro, subhirto, estriado; pedicelos glabros, subhirtos, duas vezes mais longos que os frutos; bractéola sacado-galeada, séssil ou curto pedicelada. Fruto jovem ca. 1,5 mm compr., ovado, sulcado, tetragonal, ápice agudo; estigmas curvos.
Habitat: floresta ombrófila densa baixo-montana; desenvolve-se no sub-bosque, fazendo parte do estrato arbustivo, em local úmido.

Distribuição geográfica: Brasil, Rio de Janeiro.

Material examinado: sub-bosque, VIII.1984, fl., E. F. Guimarães et al. 1459 (RB).

Material adicional examinado: BRASIL. RIO DE JANEIRO: Nova Friburgo, Rio Bonito de Lumiar, pousada dos Cristais, 721 $\mathrm{m}$ alt., $22^{\circ} 2425^{\prime} \mathrm{S} 42^{\circ} 25$ 72' W, 1.III.2004, fr., R. C. Forzza et al. 2760 (RB).

Espécie considerada rara no estado do Rio de Janeiro, assinalada na Reserva Biológica de Poço das Antas como uma nova coleta além da localidade típica.

3. Ottonia anisum Spreng., Neue Entd. 1: 255. 1820.

Arbusto 1,5 m alt. Caule 2-3 mm diâm., estriado-pubescente. Folhas com pecíolo $2-$ 5 mm compr., estriado-hirto; lâmina 10-14 × $3,2-5 \mathrm{~cm}$, papirácea ou membranácea, assimétrico-lanceolada, ápice acuminadofalcado, base assimétrica, aguda ou obtusa, glabra na face adaxial, com tricomas superpostos na nervura mediana abaxial. Racemo 2,5-8 cm; raque hirta; pedúnculo 3$5 \mathrm{~mm}$ compr., estriado, hirto; pedicelos iguais ou pouco mais longos que os frutos; bractéola glabra ou hirta. Fruto 1,5-2 mm compr., ovado-tetragonal, ápice apiculado, estigmas eretos ou curvos.

Nomes populares: jaborandi, jaborandi-domato ou jaborandi-da-mata-virgem.

Habitat: este táxon é freqüentemente encontrado na floresta ombrófila densa baixo-montana; faz parte do estrato arbustivo, apresentando-se de forma esparsa ou constituindo às vezes, pequenas populações.

Distribuição geográfica: Brasil, nos estados de Rio de Janeiro e São Paulo.

Material examinado: 24.VIII.1989, fl., L. C. Giordano et al. 789 (RB); fazenda Portuense, 9.IX.1981, fl., E. F. Guimarães et al. 1390 (RB); sub-mata, X.1984, fl., E. F. Guimarães et al. 1440 (RB). 
É considerada medicinal, tendo em vista que suas folhas são estimulantes, entretanto, a parte da planta mais utilizada é a raiz, cuja tintura é empregada internamente para o beribéri, sendo também útil para fricções nos membros inferiores, no tratamento de nefrites periféricas; quando em contato com a mucosa bucal, tem gosto picante seguido de anestesia, constituindo um poderoso odontálgico (Silva 1911). Esta planta é ainda muito utilizada em rituais religiosos, nos conhecidos "banhos de descarrego" e "defumadores de caboclo", tendo por finalidade afastar os maus espíritos e quebrantos (Guimarães 1984). As raízes são sinalagogas, diuréticas e, se mastigadas aliviam as dores de cabeça (Mors et al. 2000). Coletada em flor em agosto, setembro e outubro.

4. Ottonia leptostachya Kunth, Linnaea 13: 586. 1839.

Arbusto 0,6-1,5 m alt., glabro. Caule 46 mm diâm., estriado. Folhas com pecíolo 0,3$1,6 \mathrm{~cm}$ compr., estriado; bainha basal; lâmina 13-15,5 × 4,9-6,5 cm, discolor, papirácea, elíptica, lanceolado-elíptica, largo-lanceolada, ápice agudo-acuminado, margem abaxial hirta ou glabra, base obtusa, aguda-subigual, peninérvea, presença ou não de glândulas não translúcidas. Racemo 2-11 cm alvoamarelado; raque subestriada; pedúnculo 5-7 mm compr., estriado; pedicelos subsésseis, mais curtos que as flores ou frutos; bractéola séssil ou curto-pedicelada. Fruto 2,5-2,6 mm compr., globoso-sulcado, tetragonal, apiculado, estigmas curvos.

Habitat: arbusto ombrófilo da mata secundária, frequiente no estrato arbustivo, ocorrendo na em área de baixada na Reserva. Em outras localidades, como no Distrito Federal, pode ser observado em matas de galeria, em altitudes de 1000-1150 m.s.m; nesse trabalho a espécie é tratada como Piper ovatum Vahl. (CarvalhoSilva \& Cavalcanti 2002).

Distribuição geográfica: Brasil, nos estados da Paraíba, Bahia, Goiás, Distrito Federal, Minas Gerais, São Paulo e Rio de Janeiro.
Material examinado: mata secundária, 9.IX.1981, fl., E. F. Guimarães et al 1332 (RB); mata secundária, XI-XII.1983, fl., $E$. F. Guimarães et al. 1359 (RB); mata secundária, XI-XII.1983, fl., E.F. Guimarães et al. 1370 (RB); mata secundária, XIXII.1983, fl., E. F. Guimarães et al. 1379 (RB); sub-bosque, VIII.1984, fl., E. F. Guimarães et al. 1439 (RB); submata, VIII.1984, fl., E. F. Guimarães et al. 1442 (RB); trilha da Pelonha, próximo da parcela, 17.V.1994, fl. e fr., J. M. A. Braga et al. 1230 (RB).

Coletada com flores em maio, agosto, setembro, novembro e dezembro, e frutificando em maio.

5. Ottonia propinqua Kunth, Linnaea 13: 583. 1839.

Fig. 1a

Arbusto 0,5-1,5 m alt. , glabro. Caule 37 mm diâm., estriado. Folhas com pecíolo estriado, 4-8 mm compr., bainha basal; lâmina 11,5-16,5 × 5,5-8,2 cm, discolor, papirácea, lanceolada, elíptico-lanceolada, oblongolanceolada, ápice agudo-acuminado, margem revoluta, glabra na face abaxial, base equilátera ou subequilátero-obtuso-cordada. Racemo 4$10 \mathrm{~cm}$; raque glabra ou subhirto-estriada; pedúnculo 5-7 mm compr., estriado, esparsohirto; pedicelos mais longos que os frutos; bractéola pedicelada. Fruto $1,9-3,0 \mathrm{~mm}$ compr., oblongo-ovóide, tetragonal-sulcado, ápice agudo.

Nomes populares: chá-bravo, falsojaborandi, jaborandi, jaborandi-do-mato, jaborandi-manso, nhaborandi ou zebrandi.

Habitat: espécie ocorrente em formações primárias e secundárias, da floresta ombrófila densa submontana, geralmente no interior das matas primárias densas e úmidas, das planícies e das encostas suaves, onde às vezes é muito abundante. Pode ainda ocorrer em capoeiras, à margem das estradas (Guimarães et al. 1978).

Distribuição geográfica: Brasil, nos estados do Pará, Ceará, Paraíba, Pernambuco, Bahia, Minas Gerais, Espírito Santo, Rio de Janeiro, São Paulo, Paraná e Santa Catarina. 
Material examinado: $25 . X .1979$, fl. e fr., $J$. P. P. Carauta \& N. Crud-Maciel 3288 (RB); morro do Pau Preto, trilha do Pau Preto, 29.X.1997, fl. e fr, J. A. Lira Neto et al. 721 (RB); mata secundária, 6.IX.1981, fl., E. F. Guimarães et al. 1159 (RB); fazenda Portuense, XI-XII.1983, fl., E. F. Guimarães et al. 1345 (RB); sub-bosque, VIII.1984, fl., E. F. Guimarães et al. 1441 (RB); subbosque, VIII.1984, fl., E. F. Guimarães et al. 1443 (RB); sub-mata, VIII.1984, fr., E. F. Guimarães et al. 1444 (RB); sub-bosque, VIII.1984, fl. e fr., E.F. Guimarães et al. 1445 (RB); sub-bosque, VIII.1984, fl., E. F. Guimarães et al. 1446 (RB); sub-bosque, VIII.1984, fl. e fr., E. F. Guimarães et al. 1447 (RB).

Os ramos folhas e raízes quando mastigados abrandam dores de cabeça. As espigas são carminatívas e estomáquicas. Nesta espécie foram isoladas várias amidas, dentre elas a piperovatina que é responsável pela ação anestésica na língua e mucosa bucal (Mors et al. 2000). A raiz dispõe de casca amarelada, aroma ativo e sabor acrepicante, provocando anestesia e salivação. É utilizada pelos indígenas como antídoto na intoxicação por cogumelos venenosos e pela água da mandioca (Peckolt \& Peckolt 1888). Encontrada florescendo de agosto a dezembro, com frutificação em agosto e outubro.

6. Peperomia corcovadensis Gard., J. Bot. 1:187. 1842.

Erva 5-10 cm alt., estolonífera, epífita ou rupícola, microscopicamente hirtela a glabrescente; ramos ascendentes da base cespitosa. Caule $1 \mathrm{~mm}$ diâm., estriado. Folhas alternas; pecíolo 2-5 mm compr.; lâmina 8$13 \times$ 5-7 mm, membranácea, glandulosa, ovada, ovado-lanceolada, ovado-elíptica, elíptico-subovada, lanceolada, ápice obtuso, estreito-obtuso, obtuso-retuso, esparsociliada, base obtusa ou aguda, glabra em ambas as faces, 3-nervada. Espiga 15-35 $\times$ $5-1 \mathrm{~mm}$, terminal; pedúnculo $1,5-2,1 \mathrm{~cm}$ compr., hirto; bractéola arredondado-peltada, glanduloso-pontuada, margens papilosoverrucosa; raque verrucosa, foveolada. Fruto 0,3-0,4 mm compr., não estipitado, ovadoelíptico, submerso, subfoveolado, ápice agudo, estigma apical, pseudocúpula pouco abaixo ou até a porção mediana.

Nomes populares: erva-de-vidro, jabotimembeca (Guimarães et al. 1984). Na área estudada, não foi registrado ainda nome vulgar. Habitat: floresta ombrófila densa baixomontana, em mata de baixada. Em Santa Catarina, é freqüente na floresta pluvial de araucária e floresta pluvial ripária, habitando tronco úmido, em local sombrio.

Distribuição geográfica: no Brasil, nas Regiões Sudeste e Sul.

Material examinado: Juturnaiba, trilha da Pelonha, 16.VIII.1995, fl., J. M. A. Braga et al. 2658 (RB).

Material adicional examinado: BRASIL. RIO DE JANEIRO: Rio das Ostras, restinga da praia Virgem, 31.X.1999, fl. e fr., $R$. $N$. Damasceno 1181 (RB).

7. Peperomia trinervis Ruiz \& Pav., Fl. Peruv. 1: 32, tab. 50, fig. b. 1798.

Fig. 1 b-c

Erva reptante, estolonífera, negroglanduloso-pontuada. Caule $3 \mathrm{~mm}$ diâm., moderado a esparsamente viloso. Folhas alternas; pecíolo $0,5-1 \mathrm{~cm}$ compr., viloso; com fileira decurrente de tricomas; lâmina 1,2-3 × 0,5-1,4 cm, membranácea, membranáceo-rígida, ovado-elíptica, elíptica, ovado-lanceolada, lanceolada, ápice agudo, agudo-falcado, acuminado, ciliado, base aguda, decurrente, glabrescente na face adaxial, esparsa a moderadamente vilosa na face abaxial, 3 5 nervada. Espiga $1,5-8,5 \times 0,1 \mathrm{~cm}$, terminal; pedúnculo $0,3-1,3 \mathrm{~cm}$ compr., glabro; bractéola arredondado-peltada; raque liso-sulcada, negro-pontuada. Fruto 0,5-0,9 mm compr., não estipitado, ovado, globoso, verrucoso-glanduloso, com ápice oblíquo, estigma subapical, sem pseudocúpula. 


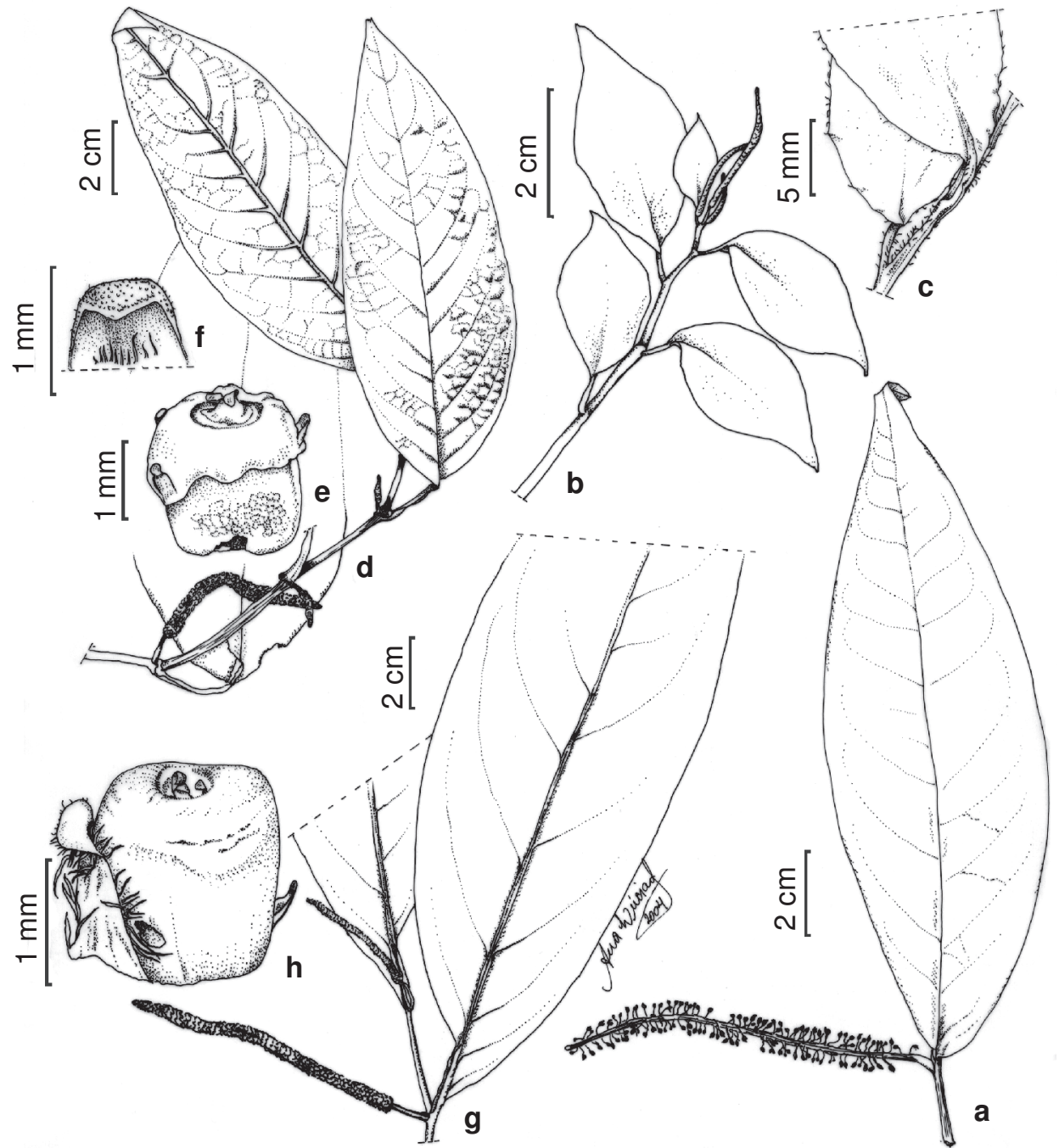

Figura 1 - a. Ottonia propinqua Kunth (Carauta 3288): ramo com inflorescência. b-c: Peperomia trinervis Ruiz \& Pav.: b. ramo com inflorescência; c. detalhe do pecíolo. d-f: Piper amplum Kunth (Braga 1830): d. ramo com inflorescência; e. Fruto; f. bractéola. g-h: Piper arboreum Aubl. var. arboreum (Lima 4955): g. ramo com inflorescência; h. fruto e bractéola.

Nomes populares: na Reserva não foi encontrada qualquer referência à denominação vulgar.

Habitat: espécie ocorrente no interior da floresta ombrófila densa submontana.

Distribuição geográfica: Bolívia, Colômbia, Equador, México, Peru e Brasil, nos estados da Bahia, Minas Gerais, Espírito Santo, Rio de Janeiro e São Paulo.

Material examinado: Juturnaiba, trilha da Pelonha, 16.VIII.1995, fl., J. M. A. Braga et al. 2687 (RB).

Planta difícil de ser encontrada, coletada florescendo em agosto.
8. Peperomia rotundifolia (L.) Kunth, Nov. Gen. Sp. 1: 65. 1815.

Erva epífita, glabra ou crespo-pubescente; ramos lisos. Caule 0,25-0,5 mm diâm., delicado. Folhas alternas; pecíolo 1,5-4 mm compr.; lâmina $2-12 \times 2-10 \mathrm{~mm}$, carnosa, quando seca membranácea ou papirácea, ovado-arredondada ou oblonga, glandulosa, arredondada; ápice arredondado, as vezes retuso ou emarginado, base arredondada, com tricomas esparsos em ambas as faces, palmati-3-nervada. Espiga 0,5$2,5 \mathrm{~cm} \times 1-1,5 \mathrm{~mm}$, terminal; pedúnculo ca. 0,5 mm compr., crespo-pubescente; bractéola 
arredondado-peltada. Fruto 0,4-0,6 mm compr., não estipitado, globoso, ovóide, ápice não mamiforme, oblíquo, desprovido de escudo rostrado, estigma subapical, sem pseudocúpula.

Nomes Populares: bejuco de alcanfor (Costa Rica), erva-de-jaboti, erva-de-vidro em Santa Catarina, jaboti-membeca, lentejuela (Cuba) ou salva-vidas; no Rio de Janeiro, não tem registro de nome vulgar.

Habitat: habita geralmente tronco e ramos das árvores, com larga dispersão e freqüência na floresta ombrófila densa (Guimarães et al. 1985).

Distribuição geográfica: Antilhas, Américas. No Brasil, nos estados do Amazonas, Pará, Pernambuco, Minas Gerais, Espírito Santo, Rio de Janeiro, São Paulo, Paraná, Santa Catarina e Rio Grande do Sul.

Material examinado: trilha do Pau Preto, margem do rio Pau Preto, 10-30 m, 24.I.1995, st., J. M. A. Braga et al. 1787 (RB).

Material adicional examinado: BRASIL. RIO DE JANEIRO: Nova Friburgo, Parque Estadual Furnas do Catite, 26.X.1986, fl., A. Vaz 427 (RB).

É epífita de folhas muito reduzidas, geralmente cultivada em vasos ou placas como ornamental. É considerada planta medicinal, sendo usada como estomáquica (Corrêa 1909; Mors et al. 2000). Os ramos desta planta quando esmagados exalam odor semelhante à cânfora e, quando mastigados, dão a sensação de frescor próprio desta substância. É considerada planta própria para a expectoração (Roig y Mesa 1945).

9. Piper amplum Kunth, Linnaea 13: 618. 1839.

Fig. $1 \mathrm{~d}-\mathrm{f}$

Arbusto 1-2,5 m alt.; ramos 5-10 mm diâm., cilíndrico-sulcados. Folhas com pecíolo 1,5-2,5 cm compr., estriado, canaliculado, bainha canaliculada basal; lâmina 19-24 ×6,5$11,5 \mathrm{~cm}$, membranácea, papirácea, glandulosotranslúcida, elíptica, oblongo-lanceolada, ovado-elíptica, ápice agudo, base profundo lobada, simétrica, obtusa, aguda, subcordada, quando assimétrica um lado 2-3 mm mais curto em relação ao pecíolo, glabra na face adaxial, esparso-pilosa ou glabra nas nervuras da face abaxial; nervuras secundárias 10-12 (14), dispostas até o ápice, salientes na face adaxial. Espiga 5-9,5 × 0,2-0,4 cm, ereta; pedúnculo 0,7-1,6 cm compr.; bractéola cuculadocrescente, glabra; estames 4; ovário com estilete curto ou séssil, estigmas 3 , filiformes. Fruto 1-2 mm compr., obovóide, oblongo, subanguloso, glabro, depresso no ápice, estigmas persistentes.

Nomes populares: caapeba, jaborandi, murta ou pariparoba.

Habitat: espécie muito freqüente e ocorrente em formações primárias e secundárias, da floresta ombrófila densa submontana; sua ocorrência em floresta secundária denota sua exigência de luz, e quando nas florestas primárias necessita de clareiras para seu desenvolvimento.

Distribuição geográfica: Brasil, nos estados da Bahia, Minas Gerais, Espírito Santo, Rio de Janeiro e Santa Catarina.

Material examinado: fazenda Portuense, XI.1983, fl., E. F. Guimarães \& L. Mautone 1375 (RB); 6.IX.1981, fl., E. F. Guimarães et al. 1170 (RB); fazenda Portuense, XII.1983, fl., E. F. Guimarães et al. 1382 (RB); Juturnaiba, estrada após a casa do Sr. Aristides em direção ao rio Aldeia, 10-30 m, 25.I.1995, fl., J. M. A. Braga et al. 1830 (RB).

Foram identificados monoterpenos, como os constituintes majoritários desta espécie (Santos et al. 2001), que é útil para aliviar a indisposição do fígado (Mors et al. 2000). Floresce de setembro a janeiro.

10. Piper arboreum Aubl., Hist. Pl. Guiane 1: 23.1775.

Fig. 1g-h

Arbusto 1-4 m alt.; ramos 4-8 mm diâm., cilíndrico-sulcados. Folhas com pecíolo 2-4 cm compr., estriado; bainha percorrendo toda extensão do pecíolo, canaliculado-alada; lâmina 16-27 × 6-10 cm, membranácea, papirácea, oblongo-elíptica, ovada, oblongolanceolada, ápice agudo-acuminado, base 
inequilátero-aguda, profundo-cordadoauriculada ou com um dos lados agudo, 1$2,5 \mathrm{~cm}$ mais curto em relação ao pecíolo, glabra em ambas as faces; nervuras secundárias dispostas até o ápice. Espiga $7-12 \times 0,3-0,5 \mathrm{~cm}$, ereta; pedúnculo 0,5-2 cm compr.; bractéola triangular-peltadofranjada; estames 4; ovário com estilete curto ou séssil, estigmas 3, persistentes, filiformes. Fruto $0,8-1 \mathrm{~mm}$ compr., oblongo, glabro, lateralmente achatado, estigmas persistentes.

\section{Chave para as variedades de $P$. arboreum da Reserva Biológica de Poço das Antas}

1. Folhas glabras em ambas as faces P. arboreum var. arboreum 1 '. Folhas com tricomas na face abaxial, principalmente ao longo das nervuras

P. arboreum var. hirtelum

10.1. Piper arboreum Aubl. var. arboreum Nomes populares: alecrim-de-angola, fruto-de-morcego, jaborandi, jaborandi-dorio, jaborandi-falso, jaborandi-pimenta, nhamborandi, palim, pau-de-angola, pimentado-mato, pimenta-dos-índios, raiz-de-pahiu. Habitat: espécie muito freqüente na floresta ombrófila densa, crescendo em formações secundárias em matas de encosta, não raro presente na margem de clareiras; comum em restinga, em mata alagadiça.

Distribuição geográfica: ampla distribuição, ocorrendo desde a América Central até o Sul do Brasil, neste assinalada para o Amazonas, Amapá, Pernambuco Bahia, Rio de Janeiro, São Paulo, Paraná e Santa Catarina.

Material selecionado: trilha Rodolfo Sul, 6.XII.1993, fl.e fr., C. Luchiari et al. 163 (RB); 14.IX.1977, fl., J. P. P. Carauta et al. 2589 (RB, GUA); Pau do Gancho, prox. a fazenda da Kombi, 26.XI.1992, fl. e fr., H. C. Lima et al. 4480 (RB); mata do rio Pau Preto, 7.II.1995, fr., C. M. Vieira et al. 693 (RB, F); trilha atrás do prédio da Educação Ambiental, 20.X.1994 fl. e fr., $H$. C. Lima et al. 4955 (RB); 24.X.1979, fl., D. Araújo 3373 (GUA); 27.IX.1981, fl., D. Araújo \& M. F. V. dos Santos 4640 (GUA); VIII.1984, fl. e fr., E. F. Guimarães et al. 1438 (RB); mata de baixada, capoeirão, VIII.1984, fl. e fr., $E$. F. Guimarães et al. 1462 (RB); trilha do
Pau Preto, margem do rio Pau Preto, 1030 m, 24.I.1995, fr., J. M. A. Braga et al. 1791 (RB).

É empregada como sudorífera, afrodisíaca, para o trato de reumatismos, sendo também carminatívas; as folhas em infusão são usadas em banhos (Mors et al. 2000); na Amazônia é utilizada sob a forma de chá contra resfriados, bronquites e gripes fortes (Van den Berg 1993). As folhas e ramos jovens são úteis para dores de dente; a raiz é empregada na preparação do curare. (Peckolt \& Peckolt 1888). É também considerada alimento de morcegos. Floresce e frutifica de agosto a abril.

10.2. Piper arboreum var. hirtelum Yunck., Ann. Missouri Bot. Gard. 37 (1): 64. 1950.

Nomes populares: os mesmos da variedade típica.

Habitat: variedade encontrada em locais de relativa altitude.

Distribuição geográfica: Brasil, nos estados do Amazonas, Bahia, Goiás, Distrito Federal, Rio de Janeiro, São Paulo e Paraná.

Material examinado: morro do Pau Preto, trilha do Pau Preto, 29.X.1997, fl., J. A. Lira Neto et al. 709 (RB).

Material adicional examinado: BRASIL. RIO DE JANEIRO: Parati, Boa Vista, loteamento Frade, Pousada Paraty, 10.XI.1991, fl. e fr., Y. L. G. Klein et al. 1201 (RB).

Coletada com flor em outubro. 
11. Piper caldense C. DC., Linnaea 37. 343. 1872.

Arbusto 0,5-3 $\mathrm{m}$ alt., glabro; ramos 4$12 \mathrm{~mm}$ diâm., estriados. Folhas com pecíolo 0,5-1,5 cm compr., canaliculado; bainha curta, basal; lâmina $12-17 \times 3,5-5 \mathrm{~cm}$, discolor, membranácea, castanho-glandulosa na face adaxial, translúcida, lanceolada, elíptica, às vezes obovada, ápice agudoacuminado, mucronado, margem não indulada, base não peltada, simétrica ou assimétrica, agudo-cuneada, um lado 2-5 $\mathrm{mm}$ mais curto em relação ao pecíolo, glabra; nervuras secundárias 6-8, saindo acima da base, dispostas até o ápice. Espiga $3-5 \times 0,3-0,6 \mathrm{~cm}$, esverdeado-alvacenta, ereta, sutilmente curva, reflexa na maturidade; pedúnculo 0,7-1,5 cm compr.; bractéola triangular-peltada, franjada; estames 4; ovário com estilete longo, estigmas 3, filiformes. Fruto 2,5-3 mm compr., estiloso, globoso, às vezes anguloso, glabro, agudo no ápice, estigmas persistentes.

Nomes populares: em Santa Catarina é conhecida como paguarandy; no estado do Rio de Janeiro, não foi assinalado nome vulgar para esta espécie.

Habitat: floresta ombrófila densa submontana, às vezes nas margens de córregos onde possa penetrar luz difusa (Guimarães \& Valente 2001). Ocorre também muito raramente em área de pasto.

Distribuição geográfica: arbusto com distribuição das Regiões Nordeste a Sul do Brasil, nos estados de Pernambuco, Alagoas, Bahia, Minas Gerais, Rio de Janeiro, São Paulo, Paraná e Santa Catarina.

Material examinado: prox. à BR-101, 24.II.1994, fr., C. M. Vieira et al. 545 (RB, F, NY); trilha para a Pelonha, entrada em frente a trilha Morro do Calcário, 6.III.1993, fl., C. M. B. Correia et al. 326 (RB); VIII.1984, fl., E. F. Guimarães \& L. Mautone 1404 (RB).

Coletada com flor em março e agosto; com frutos em fevereiro.
12. Piper crassinervium Kunth, Nov. gen. sp. 1: 48. 1815.

Fig. $2 \mathrm{a}-\mathrm{b}$

Arbusto 1-6 m alt., esciófilo; ramos 49 mm diâm., glabros, cilíndrico-estriados. Folhas com pecíolo 1,3-2,2 cm compr., glabro-estriado, bainha canaliculada, largobasal, estreitando-se em direção à lâmina até a porção mediana do pecíolo; lâmina 12$20 \times 5-7,5 \mathrm{~cm}$, papirácea, não castanhoglandulosa na face abaxial, translúcida, oblongo-ovada, elíptica, oblongo-lanceolada, ápice agudo-acuminado, base simétrica, aguda ou obtusa, quando assimétrica um lado 2-4 mm mais curto em relação ao pecíolo, glabra em ambas as faces ou esparso-pilosa nas nervuras da face abaxial; nervuras secundárias 4-6, saindo acima da base dispostas até ou abaixo da porção mediana. Espiga 3,5-7 $\times 0,3-0,5 \mathrm{~cm}$, ereta na frutificação; pedúnculo $0,5-1 \mathrm{~cm}$ compr., pubescente; bractéola triangular-subpeltadofranjada na margem; estames 4; ovário com estilete longo, estigmas 3, filiformes. Fruto 1,5-2,2 mm compr., estiloso, arredondadoobovóide, glabro, estigmas persistentes.

Nomes populares: pariparoba-jaguarandy, em Santa Catarina; na Reserva não foi assinalado nome vulgar.

Habitat: arbusto muito freqüente, que habita florestas secundárias em altitudes de 80-900 m. Distribuição geográfica: América do Sul; no Brasil nos estados do Amazonas, Ceará, Goiás, Minas Gerais, Rio de Janeiro, São Paulo, Paraná e Santa Catarina.

Material examinado: $14 . I X .1977$, fl., J. P. P. Carauta et al. 2601 (RB, GUA); fazenda Portuense VIII.1984, fl. e fr, E. F. Guimarães \& L. Mautone 1421 (RB).

Este arbusto constitui um importante alimento de morcegos (Guimarães \& Valente 2001); além disso alcança até 6 metros de altura, dispõe de folhas verde-escuras, brilhantes, nervação proeminente, espigas eretas com estigmas persistentes e aparentes, podendo ser cultivado como ornamental. Coletada florescendo em agosto e setembro, com frutificação em agosto. 


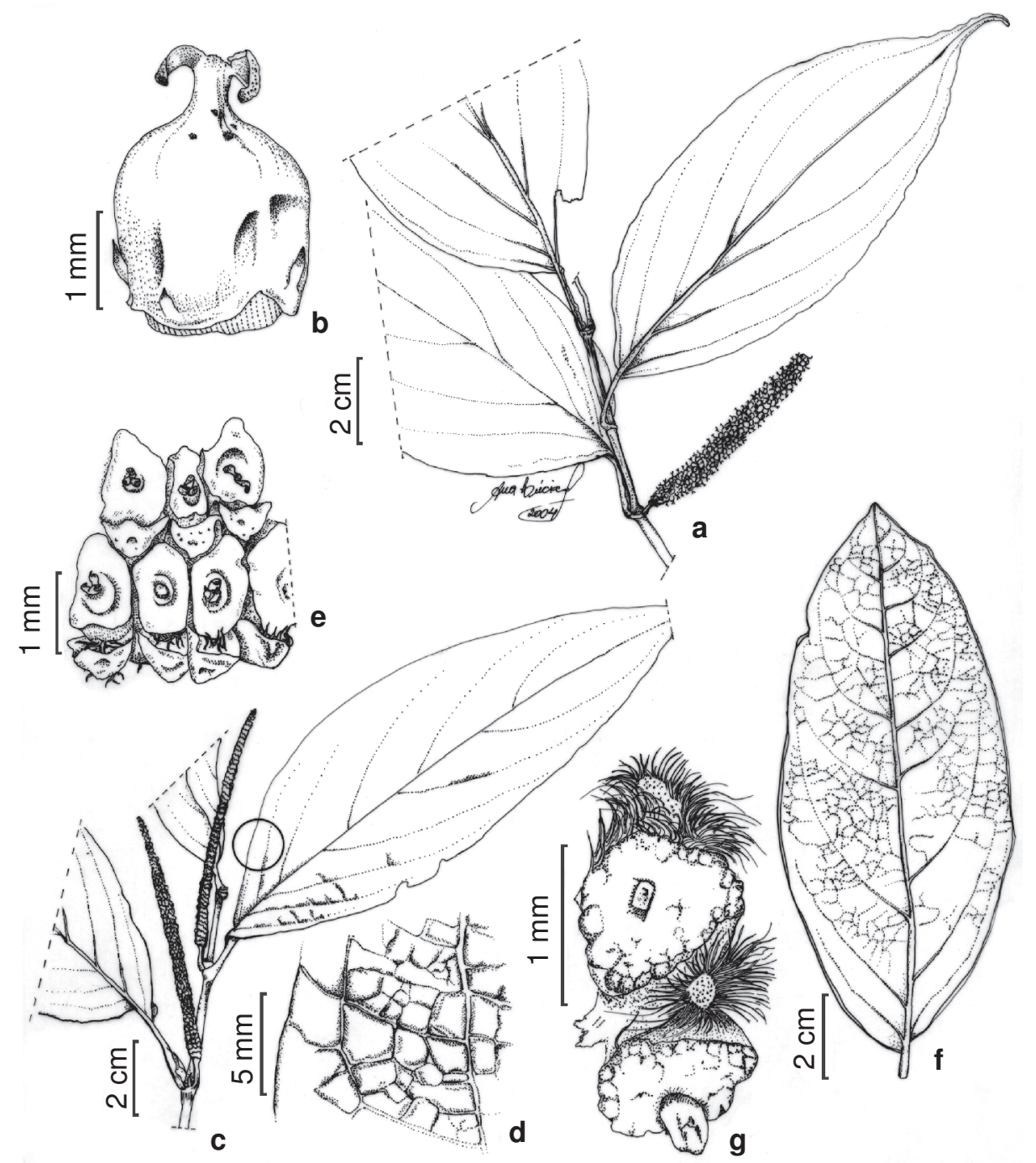

Figura 2 - a-b: Piper crassinervium Humb., Bonpl. \& Kunth (Guimarães 1421): a. ramo com inflorescência; b. fruto. c-e: Piper diospyrifolium Kunth (Correia 325): c. ramo com inflorescência; d. detalhe das nervuras impressas na lâmina foliar; e. detalhe da espiga mostrando frutos e bractéolas. f-g: Piper divaricatum G. Mey. (Guimarães 1456): f. aspecto geral da folha; g. fruto.

\section{Piper diospyrifolium (Kunth)} Kunth ex C. DC., Prodr. 16(1): 300. 1869.

Fig. 2 c-e

Arbusto $0,7-3 \mathrm{~m}$ alt.; ramos $5-7 \mathrm{~mm}$ diâm., glabros, estriado-sulcado. Folhas com pecíolo 1-3,5 cm compr., estriado-glabro; bainha alongada, alado-caduca, constituindo um canal, estreitando-se em direção à lâmina; lâmina 16-24 × 5,5-9,5 cm, discolor, subcoriácea, cartácea, papirácea, glandulosotranslúcida, ovado-oblonga, oblongo- lanceolada, elíptica, ápice agudo-acuminado, base não profundo lobada, simétrica, aguda ou obtusa, quando assimétrica um lado 2-3 mm mais curto em relação ao pecíolo, glabra na face adaxial, com tricomas hirtos nas nervuras da face abaxial; nervuras 5-9, saindo acima da base, impressas na face adaxial, salientes na abaxial, dispostas até ou pouco acima da porção mediana, não atingindo o ápice. Espiga $6,5-9 \times 0,3-0,7 \mathrm{~cm}$, branca ou verde, ereta na frutificação; pedúnculo 8-15 mm compr., 
cilíndrico, glabro; bractéolas cuculadocrescentes, subpeltadas, glabra ou glabrescentes; estames 4; ovário com estilete curto ou séssil, estigmas 3, filiformes. Fruto 2-2,1 mm compr., não estiloso, oblongo, lateralmente achatado, glabro, depresso no ápice, estigmas persistentes.

Nomes populares: conhecida na Reserva como joão-borandi.

Habitat: esta espécie semi-heliófila que habita a floresta ombrófila densa baixomontana, em local bastante úmido, é ainda pouco coletada nas regiões sudeste e sul, áreas de sua ocorrência. Na Reserva é assinalada na floresta alagadiça, fazendo parte do estrato arbustivo. É também encontrada em mata de baixada e capoeirão.

Distribuição geográfica: no Brasil ocorre nos estados do Rio de Janeiro, São Paulo e Santa Catarina.

Material examinado: trilha para a Pelonha, entrada em frente à trilha Morro do Calvário, 6.III.1993, fl. e fr, C. M. B. Correia et at. 325 (RB); trilha Rodolfo Norte, primeira trilha a esquerda após a porteira, 1.XII.1996, fl., S. J. Silva Neto et al. 761 (RB); fazenda Portuense, VIII.1984, fl. e fr., E. F. Guimarães et al. 1422 (RB); mata alagadiça, 18.IV.1977, fl. e fr, $D$. Araújo \& R. F. Oliveira 1618 (GUA); VIII.1984, fl., E.F. Guimarães et al. 1448 (RB); VIII.1984, fl., E. F. Guimarães \& L. Mautone 1453 (RB); fazenda Portuense, VIII.1984, fl., E. F. Guimarães \& L. Mautone 1455 (RB); mata de baixada, VIII.1984, fl., E. F. Guimarães \& L. Mautone 1461 (RB).

Esta espécie é considerada rara, uma vez que existem poucas coletas (datando de 1878, 1888, 1929, 1945, 1981, 1993, $1995 \mathrm{e}$ 1996). Estes intervalos de coleta mostram a pouca representatividade deste táxon nos acervos dos herbários. Sua utilidade é desconhecida até o momento. Floresce em março, abril, agosto, novembro e dezembro e frutifica em março, abril e agosto.
14. Piper divaricatum G. Mey. Prim. Fl. Esseq. 15, fig. 86. $1818 . \quad$ Fig. 2.f-g.

Arbusto 2-7 m alt., glabro, mais ou menos dotado de glândulas; ramos estriadosulcados quando secos, nodosos. Folhas com pecíolo 0,5-2 cm compr., sulcado em direção a lâmina, provido de bainha curta na base; lâmina 9-17 ×3,5-7 cm, discolor, papiráceomembranécea a subcoriácea, brilhante em ambas as faces, oblongo-elíptica, lanceolada ou raramente ovada, ápice agudo, base não profundo lobada, assimétrica, decurrente, revoluta na margem; nervuras 7-9 em cada lado, dispostas até o ápice, ascendentes em relação a principal, padrão de nervação misto, camptódromo-broquidódromo. Espigas 3,5$6 \times 0,3-1 \mathrm{~cm}$, eretas, pêndulas ou curvadas; pedúnculo 0,7-1 cm compr., glabro; bractéolas arredondado-triangular, peltadas, densamente franjada na margem, pedicelo piloso; estames 4; ovário com 3 estigmas sésseis. Fruto 1,5-2,5 mm compr., não estiloso, obpiramidal ou tetragonal, achatado na base, sub-arredondado, convexo ou sub-apiculado no ápice, comprimido lateralmente, glanduloso, estigmas persistentes.

Nomes populares: betle ou betro,

Habitat: arbusto semi-ombrófilo, frequiente nas restingas, na floresta alagadiça, fazendo parte do estrato arbustivo, crescendo entre espécies de Bombacaceae, Clusiaceae, Moraceae e Zingiberaceae (Guimarães et al. 1988), às vezes assinalado em capoeiras.

Distribuição geográfica: Brasil, nos estados do Amazonas, Pernambuco, Bahia, Minas Gerais, Espírito Santo e Rio de Janeiro.

Material examinado: área do plantio, BR 101, 250 m, 15.XI.1994, fl. e fr., C. Luchiari et al. 436 (RB); mata do Pau Preto, 7.II.1995, fr., C. M. Vieira et al. 695 (RB); margens do rio São João, entre a BR 101 e a ponte da linha férrea, 15.III.1994, fl. e fr., D. S. Farias et al. 170 (RB); 4.IX.1981, fl., E. F. Guimarães et al. 1145 (RB); fazenda Portuense, VIII.1984, fl. e fr, E. F. Guimarães \& L. Mautone 1423 (RB); VIII.1984, fl., E. F. Guimarães et al. 1425 (RB); mata da 
pedreira, VIII.1984, fl., E. F. Guimarães et al. 1451 (RB); idem, VIII.1984, fl. e fr., $E$. F. Guimarães \& L. Mautone 1456 (RB); idem, VIII.1984, fl. E. F. Guimarães \& L. Mautone 1458 (RB); capoeira, 8.XI.1979, fl.;fr., D. Araújo \& M. dos Santos 3419 (GUA); próximo ao Rio São João, a beira da BR 101 em brejo, 16.III.1984, fr., D. Araújo \& M.C. Maciel 6140 (GUA); idem, trilha da Pelonha, próximo da parcela de fitossociologia (PMA) 3.II.1995, fr., J. M. A. Braga et al. 1901 (RB).

A raiz desta espécie é aromática e tem sabor semelhante ao do gengibre. A população utiliza a planta sob forma de infusão, para combater cólicas e dores reumáticas. As raízes e folhas cozidas são usadas em banhos com finalidade antireumática (Peckolt \& Peckolt 1888). Floresce em março, agosto, setembro, novembro e frutifica em fevereiro, março, agosto e novembro.

\section{Piper hispidum Sw., Prodr.: 15. 1788.}

Arbusto 1-4 m alt., com tricomas híspidoescabros, não retrorsos; ramos 2-6 mm cilíndrico-sulcados. Folhas com pecíolo 0,3-1 cm compr., cilíndrico; bainha curto-basal; lâmina 8,5-16 × 3,2-6,5 cm, membranácea, glanduloso-translúcida, oblongo-lanceolada, elíptica, ápice agudo-acuminado, base não profundo lobada, obliquamente arredondada ou aguda, um lado 2-6 mm mais curto em relação ao pecíolo, lepidoto-escabra na face adaxial, tricomas híspidos, hirsutos nas nervuras da face abaxial, rugosa quando envelhecida, nervuras secundárias maiores 5-6, saindo acima da base, ascendentes, salientes na face adaxial, dispostas até ou abaixo da porção mediana. Espiga $5-7 \times 0,2-0,3 \mathrm{~mm}$, ereta, às vezes apiculada; pedúnculo $0,8-1,2 \mathrm{~cm}$ compr.; bractéola triangular-subpeltada, franjada; estames 4; ovário com estilete curto ou séssil, estigmas 3, filiformes. Fruto 1,9-2 mm compr., não estiloso, oblongo, lateralmente achatado, papiloso-pubescente no ápice, estigmas persistentes.

Nomes populares: aperta-joão, aperta-ruão, beque, higuillo oloroso na Costa Rica, matico matico-falso e plantanilo-de-cuba ou cordocillo-blanco na América Central.

Habitat: floresta ombrófila densa, ocorrendo em local muito úmido, matas de galeria, em altitudes de 750-1000 m.s.m (Carvalho-Silva 2002), matas sombrias úmidas, sendo também freqüente em áreas ensolaradas, em restingas. Distribuição geográfica: América Central, Antilhas, América de Sul. No Brasil, nos estados do Amazonas, Pará, Ceará, Pernambuco, Bahia, Rio de Janeiro, Paraná, Santa Catarina, Goiás, Distrito Federal e Mato Grosso.

Material examinado: fazenda Portuense, VIII.1984, st., E. F. Guimarães \& L. Mautone 1426 (RB); VIII.1984, fl., E. F. Guimarães \& L. Mautone 1453 (RB); VIII.1984, st., E. F. Guimarães et al. 1460 (RB); VIII.1984, st., E. F. Guimarães et al. 1437 (RB); 4.IX.1981, st., E. F. Guimarães et al. 1083 (RB).

Representa um táxon polimorfo, especialmente no que diz respeito às suas folhas, com dimensões e formas distintas, não raro havendo dificuldades para sua identificação que é, geralmente favorecida pelas espigas eretas e pedúnculos curtos. É utilizada como planta medicinal, suas raízes folhas e frutos são adstringentes, estimulantes, empregadas para combater a cistite, inflamação da bexiga e deter hemorragias traumáticas; (Roig y Mesa 1945; Silva 1911). As folhas são ainda usadas frescas como emplastos, para hérnia de umbigo de crianças (Peckolt \& Peckolt 1888). A planta é empregada também para o descongestionamento do fígado; as folhas usadas internamente sob a forma de infusão, são indicadas para desinterias, e externamente pela sua adstringência, em banhos, evitando nas mulheres a queda do útero (Peckolt 1941). O chá da decocção da folha é útil para o tratamento da malária (Milliken 1997). Coletada florescendo em agosto.

16. Piper hoffmannseggianum Roem. \& Schult., Mant. 1: 242. 1822.

Arbusto 1,4-2 m alt., glabro, ciófilo. Folhas com pecíolo 5-7 $\mathrm{mm}$ compr., canaliculado, com bainha na base; lâmina 10- 
$17 \times 3,5-5 \mathrm{~cm}$, discolor, semi-cartácea, membranáceo-rígida, lanceolada, oblongolanceolada, ápice acuminado, base aguda, não peltada, assimétrica, nervuras 8-12, dispostas até o ápice da lâmina, pálido-virentes quando secas. Espiga 5-11 ×0,2-0,5 cm, esverdeada, ereta, raramente curva; pedúnculo $1-1,2 \mathrm{~cm}$ compr; raque fimbriada ou pubérula, flores laxas, bractéolas sacado-galeadas, glandulosas; estames 4, com anteras reniformes; ovário com 4 estigmas sésseis. Fruto ca. 1,5 mm compr., não estiloso, suborbicular, oblongo, tetragonal, lateralmente sulcado, estigmas persistentes.

Nomes populares: jaborandi, joão-barandino, joão-barradin.

Habitat: floresta ombrófila densa baixomontana em estágio secundário, em ca. 250 $m$ de altitude. Habita áreas de encosta úmidas e sombrias, podendo, entretanto, habitar clareiras ensolaradas.

Distribuição geográfica: Brasil, nos estados do Pará, Minas Gerais, Bahia e Rio de Janeiro.

Material examinado: área da parcela de morrete, entre as linhas 6 e 10, 9.VII.1996, fl., S. J. Silva Neto et al. 892 (RB).

Material adicional examinado: BRASIL. RIO DE JANEIRO: Paraty, estrada próxima ao Rio dos Meros, beira da mata, 10.V.1994, fr., R. Marquete 1747 (RB).

Planta muito utilizada como paliativo para dor de dente, sendo também sudorífera. Coletada florescendo em julho.

17. Piper malacophyllum (C. Presl) C. DC., in DC. Prodr. 16(1): 337. 1869. Fig. 3 a-c

Arbusto 2-2,5 m alt., com tricomas escabro-pubescente, não retrorsos; ramos $2-$ 6 mm diâm., sulcados. Folhas com pecíolo $4-$ $7 \mathrm{~mm}$ compr., canaliculado, pubescente; bainha curto- basal; lâmina $12-20 \times 5-8 \mathrm{~cm}$, membranácea, glanduloso-translúcida, elíptica, oblonga, oblongo-lanceolada, ápice agudo, acuminado, margem ciliada, base não profundo lobada, cordada, às vezes aguda, um lado 2-6 $\mathrm{mm}$ mais curto em relação ao pecíolo, escabra na face adaxial, hirsuta nas nervuras da face abaxial, nervuras 5-6 (-7), saindo acima da base, dispostas até a porção mediana, salientes na face adaxial. Espiga 6-14 × 0,2-0,3 cm, curva; pedúnculo $1,5-3,5 \mathrm{~cm}$ compr., pubescente; bractéola triangular-peltada, franjada; estames 4; ovário com estilete curto ou séssil, estigmas 3, filiformes. Fruto 0,5-0,9 mm compr., não estiloso, oblongo, lateralmente achatado, subdepresso, glabro ou pubescente no ápice, estigmas persistentes.

Nomes populares: pariparoba ou pariparobamurta. Na área da Reserva não foi assinalado ainda nome vulgar para esta espécie.

Habitat: floresta ombrófila densa baixomontana, característica de clareiras em ambientes florestais, no interior da mata ocupa locais sombrios em solo úmido, ou as margens de rios (Guimarães 1999), podendo ocupar também formações secundárias, em locais ensolarados.

Distribuição geográfica: Brasil, nas Regiões Sudeste e Sul.

Material examinado: VIII.1984, fl., E. F. Guimarães et al. 1457 (RB); Juturnaiba, estrada da posse do Sr. Aristides em direção ao rio Aldeia, 10-30 m, 26.I.1995, fl., J. M. A. Braga et al. 1867 (RB).

18. Piper mollicomum Kunth, Linnaea 13: 648. 1839.

Arbusto 1-4 m alt., com tricomas vilosos, não retrorsos; ramos 2-8 mm diâm., cilíndricos. Folhas com pecíolo 0,5-1,2 cm compr., cilíndrico; bainha curto-basal; lâmina 10-19× 5-8,5 cm, discolor, membranácea, glandulosotranslúcida, ovado-oblonga, oblongolanceolada, ápice agudo, acuminado-falcado, base não profundo lobada, assimétrica, obtusocordada, um lado 2-4 mm mais curto em relação ao pecíolo, tricomas vilosos em ambas as faces, sedosos ao tato, quando envelhecidas glabrescentes na face adaxial; nervuras secundárias 5-6, saindo acima da base, dispostas até ou abaixo da porção mediana. Espiga 6-10 $\times 0,2-0,5 \mathrm{~cm}$, de amarela a verde, curva; pedúnculo 0,5-1,5 (-2) cm compr.; bractéolas subtriangular-peltado-franjada; 


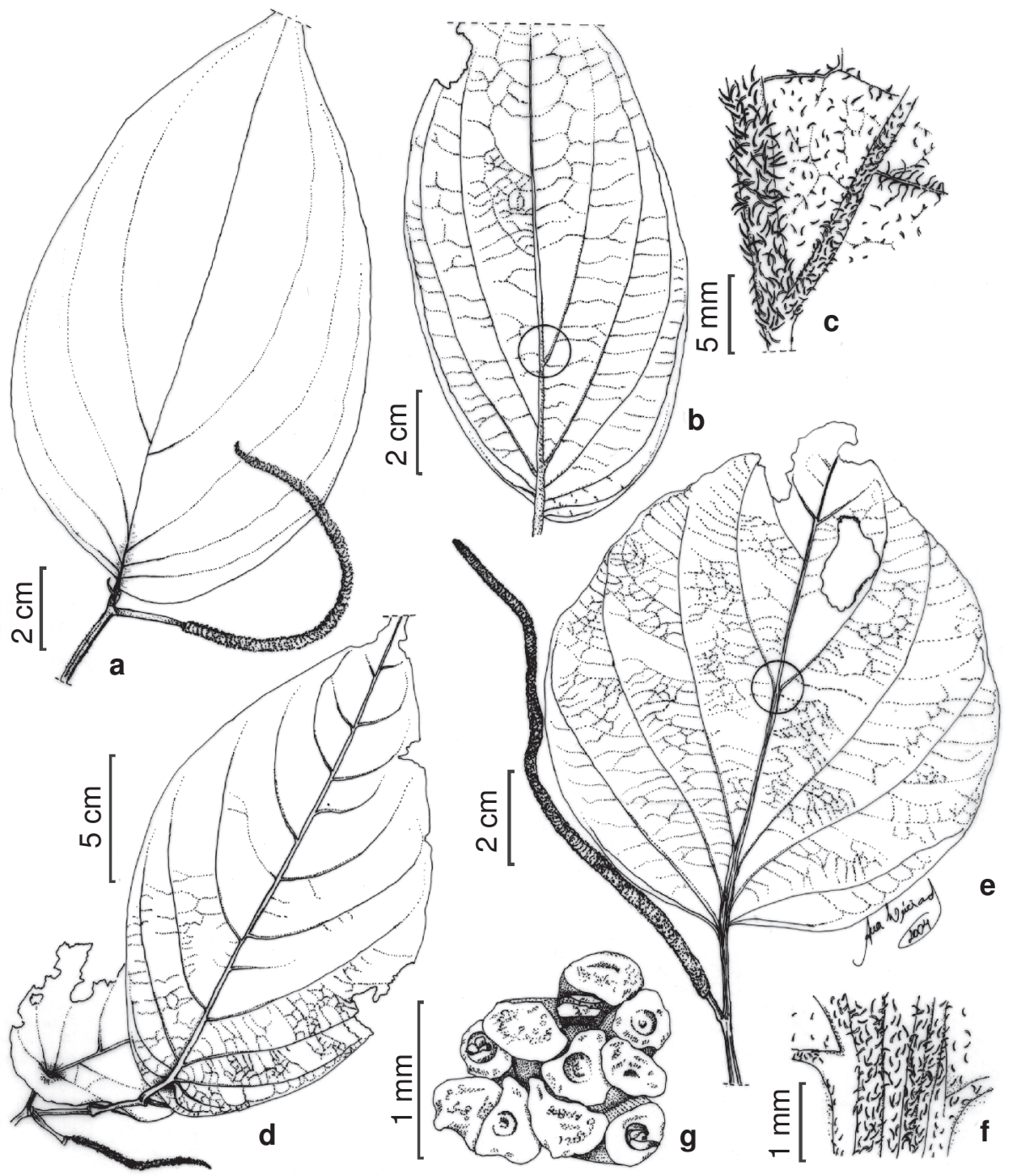

Figura 3 - a-c: Piper malacophyllum (C. Presl) C. DC. (Braga 1867): a. parte do ramo com inflorescência; b-c: face abaxial da lâmina foliar, mostrando tricomas. d: Piper scutifolium Yunck. (Lira Neto 718): ramo mostrando o detalhe da base foliar. e-g: Piper solmsianum var. hilarianum (Kunth) Yunck. (Guimarães 1485): e. parte do ramo com inflorescência; f. detalhe dos tricomas na base das nervuras da face abaxial; g. detalhe da espiga mostrando fruto e bractéola.

estames 4; ovário com estilete curto ou séssil, estigmas 3, filiformes. Fruto 1-1,1 mm compr., não estiloso, oblongo, obovóide, lateralmente achatado, reticulado, truncado, glanduloso com tricomas pubescentes no ápice, estigmas persistentes.

Nomes populares: jaborandi, jaborandimanso, rabo-de-galo.

Habitat: muito freqüente na floresta ombrófila densa baixo-montana, em altitudes entre 200600 m.s.m., tanto em locais ensolarados quanto sombreados; ocorre também em restingas; muito comum em áreas antrópicas. É freqüente em trilhas próximas a córregos (Ruschel 2004).

Distribuição geográfica: espécie ocorrendo desde o Nordeste até o Sul do Brasil; também assinalada para a Região Centro-Oeste, em altitudes de 0-900 m.s.m.

Material examinado: morro do Pau Preto, trilha do Pau Preto, 29.X.1997, fl., J. A. Lira Neto et al. 729 (RB); 14.IX.1977, fl., J. P. P. 
Carauta et al. 2612 (RB); idem, 29.10.1997, fl., J. A. Lira Neto et al. 729 (RB); 16.III.1977, fr., D. Araújo et al.1547 (GUA); fazenda Poço d'Antas, 4.XI.1981, fl., E. F. Guimarães \& L. Mautone 1140 (RB); Osmarina, 6.IX.1981, fl. e fr., E. F. Guimarães \& L. Mautone 1192 (RB); beira da estrada, VIII.1984, fl., E. F. Guimarães et al. 1424 (RB); fazenda Portuense, VIII.1984, fl. e fr., E. F. Guimarães et al. 1429 (RB); VIII.1984, fl. e fr, E. F. Guimarães \& L. Mautone 1430 (RB); VIII.1984, fl., E. F. Guimarães \& L. Mautone 1432 (RB).

Os frutos de sabor acre e picante são excitantes estomacais, sialagogos e muito utilizados para doenças venéreas; suas raízes são empregadas como paliativo nas dores de dente (Peckolt \& Peckolt 1888). As folhas são ricas em óleos essenciais a-pinene, bpinene, limonene, a-humulene, $b$-selinene $e$ benzil octanoate; estes compostos demonstraram uma ação bactericida (Guimarães \& Valente 2001). Santos et al. (2001) encontraram nesta espécie ketona, 2tri-decanona em significantes concentrações $(4,29 \%)$ no óleo essencial. Coletada florescendo em agosto a novembro, e frutificando em março, agosto e setembro.

19. Piper permucronatum Yunck., Bol. Inst. Bot. (São Paulo) 3: 11, fig. 9. 1966.

Arbusto 1-2 m alt.; ramos 2-10 mm diâm., subsulcado com tricomas glanduloso-hirtos. Folhas com pecíolo 1-1,5 cm compr., glanduloso; bainha curto-basal; lâmina 10-17 $\times 4-7 \mathrm{~cm}$, membranácea, castanho-glandulosotranslúcida, lanceolada, ápice agudo, acuminado-mucronado, margem membranácea, base não profundo lobada, inequilátero-aguda, um lado 3-5 mm mais curto em relação ao pecíolo, glabra na face adaxial, com tricomas pubescentes nas nervuras da face abaxial, nervuras secundárias 6-11, saindo acima da base dispostas até o ápice. Espiga 1,5-4 × 0,3-0,7 cm, ereta, quando em fruto; pedúnculo $1,5-3 \mathrm{~cm}$ compr., glabro ou subesparso-hirto; bractéola triangular, peltado-franjada, glandulosa; estames 4; ovário com estilete longo, espesso, estigmas 3, filiformes. Fruto 2,5-3 mm compr., estiloso, obovóide, glanduloso-glabro, apiculado, estigmas persistentes.

Habitat: floresta ombrófila densa baixomontana.

Distribuição geográfica: Brasil, nos estados do Rio de Janeiro e São Paulo.

Material examinado: margem esquerda do rio São João, 24.XI.1976, fr., $R$. F. Oliveira 263 (GUA).

A espécie é caracterizada pela folhagem verde escuro brilhante e nervuras da face abaxial providas de tricomas. Estudos químicos assinalam para esta espécie a presença de óleo essencial, consistindo principalmente de sesquiterpenos e pequena percentagem de monoterpenos. Os maiores componentes encontrados no óleo foram, "dcardinene (12\%), g muurolene (7,4\%), acadinol $(6,9 \%)$, b-caryophyllene $(6,8 \%)$, Tmuurolol (3,2 \%), a-muurolene (2,9\%), e gelemene (2,7 \%)" (Torquilho et al. 1999). Encontrada frutificando em novembro.

20. Piper richardiifolium Kunth, Linnaea 13: 668. 1839.

Arbusto 1-3 m alt.; ramos 3-12 mm diâm., sulcados. Folhas com pecíolo 5-7,3 cm compr., glabro ou minuciosamente puberulento; bainha alada até próximo à base da folha, percorrendo toda a extensão do pecíolo; lâmina $21-37 \times 7-13 \mathrm{~cm}$, membranácea, rígido-membranácea, glanduloso-translúcida, oblongo-lanceolada, elíptico-ovada, ápice agudo-acuminado, base profundo lobada, assimétrica, cordadoauriculada, um lado $0,7-1 \mathrm{~cm}$ mais curto em relação ao outro, glabra em ambas as faces, ou com tricomas hirtos nas nervuras da face abaxial, nervuras secundárias maiores 6-8, saindo acima da base, ascendentes, dispostas até o ápice, descendentes nos lobos. Espiga 21-25 × 0,4-0,5 cm, ereta ou pêndula; pedúnculo 1,6-2 $\mathrm{cm}$ compr.; bractéola triangular-subpeltada; estames 4; ovário com 
estilete curto ou séssil, estigmas 3, persistentes, filiformes. Fruto 1,1-1,2 mm compr., não estiloso, obovóide, truncado, lateralmente achatado, denso-pubescente no ápice, estigmas persistentes.

Nomes populares: pau-de-junta-do-grado, pau-de-junta em Santa Catarina. No Rio de Janeiro não foi encontrada referência vulgar para o táxon.

Habitat: espécie de ampla distribuição geográfica, encontrada na floresta ombrófila densa baixo-montana; tem seu registro associado a florestas primárias em locais úmidos e sombrios, ocorrendo ainda em locais de clareira de mata secundária.

Distribuição geografia: Brasil, nos estados de Minas Gerais, Rio de Janeiro, São Paulo, Paraná e Santa Catarina.

Material examinado: mata secundária, 6.IX.1981, st., E. F. Guimarães et al. 1200 (RB). Material adicional examinado: BRASIL. RIO DE JANEIRO: Teresópolis, Parque Nacional da Serra dos Órgãos, 31.I.1978, fl., A. H. Gentry \& A. L. Peixoto 941 (RB); 28.III.1994, fr., E. F. Guimarães et al. 1608 (RB).

Este táxon de porte elegante, folhas vistosas, inflorescências pêndulas e longas, presta-se ao cultivo para fins paisagísticos.

\section{Piper rivinoides (Kunth) Kunth ex C.}

DC., Prodr. 16(1): 312. 1869.

Arbusto ou arvoreta, 1,6-2 m alt., glabro; ramos 4-10 mm diâm., cilíndricoestriado. Folhas com pecíolo 1,5-2 cm compr., estriado; bainha curto-basal ou canaliculada, não alada; lâmina 12-18 ×6-9 cm, papirácea, esparso-glânduloso, translúcida, ovada, ovado-elíptica, ápice agudo-falcadoacuminado, base não profundo lobada, agudocuneada, nervuras secundárias 3-4, saindo acima da base, glabras na face abaxial, dispostas até o ápice. Espiga 7-12 ×0,3-0,5 $\mathrm{cm}$, ereta; pedúnculo $1,2-3 \mathrm{~cm}$ compr.; bractéola triangular-peltada, às vezes cuculada, esparso franjada ou glabra; estames 3; ovário com estilete curto ou séssil, estigmas 3, filiformes, recurvos. Fruto 1,1-
1,5 mm compr., não estiloso, obpiramidaltrigonal, glabro, estigmas persistentes.

Nomes populares: conhecida na Reserva como ruão.

Habitat: planta heliófila, que ocorre na floresta ombrófila densa submontana, sendo também freqüente em sub-bosque, não raro formando grandes populações.

Distribuição geográfica: Brasil, nos estados de Pernambuco, Minas Gerais, Rio de Janeiro, São Paulo e Santa Catarina.

Material examinado: estrada do Aristides, após a $2^{\mathrm{a}}$ porteira, 12.VII.1994, fl. e fr., $H$. C. Lima et al. 4929 (RB); trilha para fazenda Portuense, prox. entrada do cajueiro, 4.V.1994, fr., D. S. Farias et al. 210 (RB); estrada, VIII.1984, fl., E. F. Guimarães \& L. Mautone 1439 (RB); fazenda Portuense, quadrat 10, VIII.1984, fl., E. F. Guimarães \& L. Mautone 1449 (RB).

Os frutos desta espécie servem de alimento a fauna (em etiqueta de herbário: Faria et al. 210, RB). Coletada florescendo em julho e agosto e frutificando em maio e julho.

22. Piper scutifolium Yunck., Bol. Inst. Bot. (São Paulo) 3: 123, fig. 107. 1966. Fig. $3 \mathrm{~d}$ Arbusto 1-2 m alt., ramos 4-6 mm diâm., ascendentes, estriados, glabros. Folhas com pecíolos $0,7-1,2 \mathrm{~cm}$ compr., estriado; bainha curta basal; lâmina 16-23 ×4-12 cm, membranécea, papirácea, glandulososubtranslúcida, oblíqua, ovado-elíptica, elíptica, ovado-lanceolada, ápice agudo, acuminado, falcado, base arredondada, peltada, glabra na face adaxial, híspida nas nervuras da face abaxial; nervuras secundárias ca. 12 saindo acima da base, dispostas até o ápice, impressas na face adaxial, híspido-salientes na face abaxial. Espiga 6-9 × 0,2-0,3 cm, sub-eretas, ereta; pedúnculo $0,5-1 \mathrm{~cm}$ compr., glabro; flores congestas; bractéolas sacado-galeadas, pilosas; estames 4; ovário com estilete curto ou séssil, estigmas 4 . Fruto 1-1,5 mm compr., não estiloso, ovado-tetragonal, glabro, papiloso, estigmas persistentes. 
Habitat: floresta ombrófila densa baixomontana, preferindo locais úmidos e sombrios, raramente em áreas degradadas.

Distribuição geográfica: Brasil, nos estados do Rio de Janeiro e São Paulo.

Material examinado: morro do Pau Preto, trilha do Pau Preto, 29.X.1997, fl., J. A. Lira Neto et al. 718 (RB); Juturnaiba, trilha da Pelonha, 16.VIII.1995, fr., J. M. A. Braga et al. 2657 (RB).

Espécie rara no Rio de Janeiro, pouco coletada, porém de fácil identificação, dada a peculiaridade da base peltada da folha. Esta planta que prefere locais pouco degradados, estava assinalada no Estado para os municípios de Teresópolis e Parati. Como expresso por Guimarães \& Giordano (1997), a espécie também ocorrente na APA-Cairuçú foi atualmente acrescida da nova localidade na Reserva Biológica de Poço das Antas. Encontrada florescendo em outubro e frutificando em agosto.

23. Piper solmsianum var. hilarianum (Miq.) Yunck., Bol. Inst. Bot. São Paulo 3:124.1966.

Fig. 3 e-g

Arbusto 1,5-2,5 m alt.; ramos 3,5-10 mm diâm., sulcados. Folhas com pecíolo 2,5-6,5 cm compr., estriado, canaliculado; bainha não curtobasal, alongada, sutilmente alado-caduca, às vezes até a porção mediana do pecíolo; lâmina 13-21,5 × 11-18 cm, membranácea, papirácea, glandulosa na abaxial, ovada, ápice agudo, base assimétrica, truncado-arredondada, as vezes cordada, abruptamente decurrente em direção ao pecíolo, nervuras secundárias 6-8, geralmente saindo acima da base, dispostas até o ápice, as inferiores 3-4, muito salientes próximo à base, com tricomas hirtos na face abaxial. Espiga 5-14 × 0,3-0,5 cm, ereta; pedúnculo $0,6-1,5 \mathrm{~cm}$ compr.; bractéola arredondada, glabra na parte superior, depois subcrescente peltada, vilosa na inferior; estames 3 ; ovário com estilete curto ou séssil, estigmas 3 , filiformes. Fruto ca. $2 \mathrm{~mm}$ compr., não estiloso, obpiramidal-trigonal, glabro no ápice, estigmas persistentes.
Nomes populares: caapeba ou pariparoba. Habitat: floresta pluvial baixo-montana, frequiente em capoeirão, na mata de baixada. Distribuição geográfica: Brasil, nos estados de Minas Gerais, Rio de Janeiro, São Paulo, Paraná, Santa Catarina e Rio Grande do Sul. Material examinado: capoirão, mata de baixada, VIII.1984 (fl.), E. F. Guimarães \& L. Mautone 1485 (RB).

Esta variedade difere da típica por apresentar tricomas nas nervuras dorsais. Trata-se de um arbusto com folhas magnas, que aliado às espigas eretas e longas, formam um belo conjunto, podendo ser utilizado como planta ornamental. Encontrada florescendo em agosto.

24. Piper translucens Yunck., Bol. Inst. Bot. São Paulo 3: 130. 1966.

Arbusto ca. 1,5 m alt., glabro; ramos 2$3 \mathrm{~mm}$ diâm. Folhas com pecíolo 0,2-0,9 cm compr., estriado, bainha curta; lâmina 10-16 $\times 3,5-5,0 \mathrm{~cm}$, discolor, levemente assimétrica diferindo um lado em relação ao outro de 4 $5 \mathrm{~mm}$, semi-cartácea ou membranácea, translúcido-glandulosa, elíptico-lanceolada, ápice acuminado, base aguda, obtusa, nervuras secundárias 10-12, alternas, dispostas até o ápice. Espiga 4-5 × 0,15-0,4 cm esverdeada; pedúnculo $2-3 \mathrm{~mm}$ compr.; raque glabra, bractéola sacado-galeado, glabra, glandulosa com pedicelo ciliado; estames 4; ovário sulcado-glanduloso, tetragonal, estilete curto ou séssil, estigmas 4. Fruto ca. 1,5 mm compr., não estiloso, tetragonal, sulcado, glanduloso, estigmas persistentes.

Habitat: floresta ombrófila densa submontana. Distribuição geográfica: Rio de Janeiro.

Material examinado: área da parcela de morrote, entre linhas 6 e 10, 9.VII.1996, fl. e fr., S. J. Silva Neto et al. 890 (RB).

Esta espécie representa uma nova coleta para o Rio de Janeiro, sendo considerada rara dado que seu holótipo "habitat in M. Corcovado, prope Sebastianopolin, provinciae Rio de Janeiro", 
foi coletado no século XIX por Martius, depositado no herbário de Munchen (M) (Ichaso et al. 1977). Encontrada florescendo e frutificando em julho.

25. Piper umbellatum L., Sp. Pl. 1: 30. 1753.

Arbusto 1-3 m alt.; caule 0,6-2,2 cm diâm., piloso. Folhas com pecíolo 8-20 cm compr.; bainha subalada; lâmina 18-20 × 20$25 \mathrm{~cm}$, membranácea, translúcido-glandulosa, arredondado-ovada, reniforme, ápice abruptamente acuminado, base cordada, híspida em ambas as faces, 12-16 pares de nervuras palmatiformes, pilosas em ambas as faces. Espiga 5,5-9,5 × 0,2-0,4 cm, dispostas em umbelas; pedúnculo comum $0,3-3 \mathrm{~cm}$ compr., glanduloso-pubescente; pedúnculo secundário 3-5 mm compr., glandulosopubescente; bractéola triangular-subpeltada, fimbriada na margem. Flores congestas; ovário com estilete curto ou séssil, estigmas 3. Fruto $0,2-0,7 \mathrm{~mm}$ compr., não estiloso, obpiramidal, anguloso, glabro, glanduloso, estigmas persistentes.

Nomes populares: espécie anteriormente conhecida como Pothomorphe umbellatum. (L.) Miq.(Guimarães et al. 1978), tem como nomes populares aguaxima; baquina catajé, mamjerioba em Cuba; capeba, caa-peuá, cipó-de-cobra, folha-de-santa-maria-kidua pelos índios Chami da Colômbia; lençol-desanta-barbara, malvarisco, malvavisco, pariparoba, periparoba; santa-maria na Costa Rica; santilla de culebra no México e, nas Antilhas, pimienta de flores em ombela (Grosourdy 1864). Na Reserva não foi assinalado ainda nome vulgar.

Habitat: espécie heliófila que ocorre na floresta ombrófila densa submontana, geralmente na orla da mata em capoeiras e capoeirões, em locais sombrios ou ensolarados.

Distribuição geográfica: com distribuição nas Américas Central e do Sul e Antilhas. No Brasil, ocorre em todas as Regiões.

Material examinado: 9.IX.1981, estéril, $E$. F. Guimarães \& L. Mautone 1342 (RB);
VIII.1984, fl., E. F. Guimarães \& L. Mautone 1463 (RB).

Esta planta considerada medicinal é empregada nas doenças do baço, rim contra inchaços ou inflamações e como antimalárica. No fígado possui a propriedade de estimular a secreção biliar, além de fluidificá-la; é ativa ainda para aumentar o apetite e ativar a digestão, entretanto, quando utilizada acima da posologia normal, isto é, 10 gramas para 1 litro de água (Vieira 1992), provoca vômitos e cólicas (Peckolt 1941). Suas folhas, raízes aromáticas e cascas são empregadas geralmente sob a forma de chá, emplastos ou sucos, nas doenças respiratórias e afecções da bexiga (Rocha 1919). É muito útil como cicatrizante (Fonseca 1940). Assinala-se a presença de óleo essencial tendo a assarona como componente principal. Esta espécie é considerada útil para a culinária (Zurlo \& Brandão 1989, Guimarães \& Giordano, 2004), e as folhas dos ramos jovens são antiescorbúticas (Grosourdy 1864). Encontrada florescendo em agosto.

\section{Conclusões}

As espécies analisadas na Reserva Biológica de Poço das Antas propiciaram o conhecimento da grande necessidade de realização de coletas de Piperaceae no estado do Rio de Janeiro. Com base nestes estudos, verificou-se que alguns destes táxons foram citados pela primeira vez para a região, como observado em Ottonia angustifolia, O. albopunctata, Piper translucens, P. scutifolium, e nas três espécies de Peperomia.

\section{Agradecimentos}

Ao Conselho Nacional de Desenvolvimento Científico e Tecnológico CNPq e a Coordenação de Aperfeiçoamento de Pessoal de Nível Superior - CAPES, pelas bolsas concedidas; aos curadores dos herbários pelo empréstimo dos materiais e à Petrobrás pelo convênio com o Programa Mata Atlântica: 610.4.025.02.3 JBRJ/Petrobrás. 


\section{REFERÊNCIAS BIBLIOGRÁFICAS}

Carvalho-Silva, M. \& Cavalcanti, T. B. 2002. Piperaceae. In: Cavalcanti T. B. \& Ramos A. E. (org.). Flora do Distrito Federal, Brasil, vol. 2. Embrapa Recursos Genéticos e Biotecnologia, Brasília. Pp. 91-124.

Corrêa, M. P. 1909. Flora do Brazil: algumas plantas úteis, suas aplicações e distribuição geographica. Typographia da estatística, Rio de Janeiro, 154p.

Fonseca, E. T. 1940. Plantas medicinales brasileñas. Rio de Janeiro, Brasil, 102p.

Grosourdy, D. R. 1864. El Médico Botânico Criolo. Tomo I parte primeira e Tomo II parte segunda. Libréria de Francisco Brachet, Paris. Pp. 511-512.

Guimarães, E. F. 1984. Notas em Piperaceae II. Considerações sobre o gênero Ottonia Sprengel no Brasil. Boletim do Museu Botânico Kuhlmann 7(3): 61-84. 1999. Piperaceae. In: Melo, M. M. R. F.; Barros F.; Chiea, S. A. C.; Kirizawa, M; Jung-Mendaçolli, S. L. \& Wanderley, M. G. L.(eds.). Flora Fanerogâmica da Ilha do Cardoso. São Paulo. Instituto de Botânica 6: 15-43.

Guimarães, E. F. \& Giordano, L. C. S. 1997. Notas em Piperaceae IV. Piper scutifolium Yunck., espécie rara no estado do Rio de Janeiro, Brasil. Bradea 8(8): 41-43. 2004. Piperaceae do Nordeste Brasileiro I: estado do Ceará. Rodriguésia 55(84): 21-46.

Guimarães, E. F.; Ichaso, C. L. F. \& Costa, C. G. 1978. Piperáceas - Ottonia, Sarcorhachis, Pothomorphe. In: Reitz, R. (ed.) Flora Ilustrada Catarinense, 26p. 1984. Piperaceas. 4. Peperomia. In:

Reitz, R. (ed.). Flora Ilustrada Catarinense. Itajaí, 112p.

Guimarães, E. F.; Ichaso, C. L. F. \& Mautone, L. 1985. Peperomia Ruiz e Pav. do Parque Nacional da Serra dos Órgãos. Boletim do Museu Botânico Kuhlmann 8: 15-50.

Guimarães, E. F.; Mautone, L. \& Mattos Filho, A. 1988. Considerações sobre a Floresta
Pluvial Baixo-Montana. Fundação Brasileira para a Conservação da Natureza 23: 45-54.

Guimarães, E. F. \& Valente, M. C. 2001. Piperáceas - Piper. In: Reitz, R. (ed.). Flora Ilustrada Catarinense. Itajaí, Santa Catarina 104p.

Holmgren, P. K.; Holmgren, N. H. \& Barnett, L. C. 1990. Index Herbariorum. Part. 1: The Herbário of the World. Regnum vegetabile. $8^{\text {a }}$ ed. New York Botanical Garden, New York, 693 p.

Ichaso, C. L. F.; Guimarães, E. F. \& Costa, C. G. 1977. Piperaceae do município do Rio de Janeiro I. O gênero Piper L. Arquivos do Jardim Botânico do Rio de Janeiro 20: 145-188.

IBDF - Instituto Brasileiro de Desenvolvimento Florestal / Fundação brasileira para conservação da natureza. 1981. Plano de manejo: Reserva biológica de Poço das Antas. Gráfica brasiliana, Brasília, 94p.

Milliken, W. 1997. Plants for Malaria, Plants for Fever: Medicinal species in Latin America - a bibliographic survey. The Royal Botanic Gardens, Kew, 116p.

Mors, W. B.; Rizzini, C. T. \& Pereira, N. A. 2000. Medical Plants of Brazil. Reference Plubications, Inc., Algonac, Michigan, 501p.

Peckolt, T. \& Peckolt, G. 1888. História das plantas medicinaes e úteis do Brazil. Laemmert, Rio de Janeiro, 1369p.

Peckolt, W. 1941. Contribuição a Matéria Médica Vegetal do Brasil. Memórias do Instituto Butantan 15: 59-68.

Rocha, C. F. D. da; Goodoy Bergallo, H. de; Santos Alves, M. A. dos; Van Sluys, M. 2003. A Biodiversidade nos Grandes Remanescentes Florestais do Estado do Rio de Janeiro e nas Restingas da Mata Atlântica. RIMA, São Carlos, São Paulo, 134 p.

Rocha, F. D. 1919. Botânica Médica Cearense. Fortaleza - Ceará. Pp. 36-37.

Roig y Mesa, J. T. 1945. Plantas medicinales. vol. 2. Ministerio de Agricultura, Serviço de publicidade y Divulgación, Habana, Republica de Cuba, 872 p. 
Ruschel, D. 2004. O Gênero Piper (Piperaceae) no Rio Grande do Sul. Revista Brasileira de Biociências 2 (2): 103-129.

Santos, P. R. D.; Moreira, D. L.; Guimarães, E. F. \& Kaplan, M.A.C. 2001. Essential oil of 10 Piperaceae species from the Brazilian Atlantic Forest, Phytochemistry 58: 547-551.

Silva, F. R. M. 1911. Contribuição para o Estudo da Flora Brazileira. Typ. do Journal do Commercio de Rodrigues, Rio de Janeiro, 158p.

Torquilho, H. S.; Pinto, A. C.; Godoy, R. L. O. \& Guimarães, E. F. 1999. Essential oil of Piper permucronatum Yunck. (Piperaceae) from Rio de Janeiro, Brazil. Journal Essential oil 11: 429-430.

Van Den Berg, M. E. 1993. Piperaceae In: Van Den Berg, M. E. Plantas Medicinais na Amazônia - contribuição ao seu conhecimento sistemático. PR/MCT/ CNPq, Belém, p.55-66.
Veloso, H. P.; Rangel Filho, A. L. R.; Lima, J. C. A. 1991. Classificação da Vegetação Brasileira, Adaptada a um Sistema Universal. IBGE, Departamento de Recursos Naturais e Estudos Ambientais, Rio de Janeiro, 124p.

Vieira, L. S. 1992. Fitoterapia da Amazônia: Manual de Plantas Medicinais (A Farmácia de Deus). $2^{\mathrm{a}}$ ed., Agronômica Ceres, São Paulo, 347 p.

Yuncker, T. G. 1972. The Piperaceae of Brazil I: Piper - Groups I, II, III, IV. Hoehnea 2: 19-366. 1973. The Piperaceae of Brazil II: Piper - Group V; Ottonia; Pothomorphe; Sarcorhachis. Hoehnea 3:121-144. 1974. The Piperaceae of Brazil III: Peperomia; taxa of uncertain status. Hoehnea 4: 71-413.

Zurlo, C. \& Brandão, M. 1989. As ervas comestíveis: descrição, ilustração e receitas. Editora Globo Rural, Coleção do Agricultor: Ecologia, 167 p. 